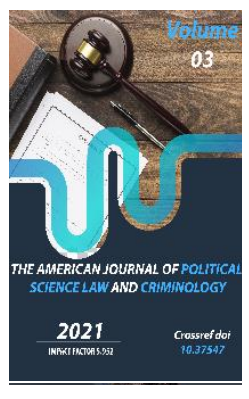

\title{
Practical Problems Of Implementation Of Arrests
}

\author{
Ulmas Sharipov \\ Lawyer Of The Firm Of "Law Protect", Tashkent, Uzbekistan
}

Journal Website: http://usajournalshub.c

om/index,php/tajpslc

Copyright: Original content from this work may be used under the terms of the creative commons attributes 4.0 licence.

\section{ABSTRACT}

The purpose of writing this article is to show that in practice the law enforcement agencies conducting pre-trial investigation and preliminary investigation do not strictly follow the detention procedure established by the Code of Criminal Procedure, although the grounds for detaining detainees are not sufficient. by deciding to detain the accused and allegedly facilitating the preliminary investigation through this "method", ie the violation of the rights and interests of the suspects and accused persons involved in the criminal proceedings as a result of the discovery of the crime and the use of suspects as a means of proving guilt being put. The main purpose of writing this article is to prevent these cases and to amend the legislation.

\section{KEYWORDS}

Detention, pre-trial investigation, preliminary investigation, suspect, accused, defendant, evidence.

\section{INTRODUCTION}

In his speech on the occasion of the 27 th anniversary of the Constitution of the Republic of Uzbekistan, President Sh.M.Mirziyoyev said that the effectiveness of any democratic reforms, the main guarantee of peace and development is directly related to the Constitution and the rule of law, as well as human rights and freedoms. stressed that 
respect for human dignity is an integral part of the open, free and just society we are building [1].

In recent years, large-scale work has been carried out in our country to ensure reliable protection of the rights and freedoms of citizens, first of all, from criminal encroachment, as well as to prevent the humiliation of their honor and dignity, the restriction of their legitimate interests.

Judicial and legal reforms are based on constitutional principles such as the rule of law, equality of citizens before the law, the presumption of humanity, justice and innocence.

On the implementation of the Action Strategy for the five priority areas of development of the Republic of Uzbekistan in 2017-2021, a number of normative and legal acts aimed at ensuring true independence and freedom of the judiciary, improving the quality and transparency of justice, expanding the use of habeas corpus.

However, in criminal proceedings, ie preinvestigation, which is a stage of criminal proceedings, and during the preliminary investigation, the rights and freedoms of persons involved in criminal proceedings are violated, including unreasonable and illegal coercive measures against them to solve crimes and prove the guilt of suspects and accused The use of outdated investigative methods, such as the use of, is very common.

According to Article 19 of the Constitution of the Republic of Uzbekistan, the rights and freedoms of citizens enshrined in the Constitution and laws are inviolable, and no one has the right to deprive or restrict them without a court decision [2].
The rights of citizens provided for in this Article, provided for in the Constitution of the Republic of Uzbekistan, are divided into such types as personal rights and freedoms, political rights and socio-economic rights.

This article refers to citizens, ie citizens of the Republic of Uzbekistan, foreign citizens residing in the Republic of Uzbekistan and stateless persons.

Citizens of the Republic of Uzbekistan, foreign citizens and stateless persons have and enjoy the personal rights and freedoms provided for in our Constitution, as well as socio-economic rights.

Only citizens of the Republic of Uzbekistan may enjoy political rights and freedoms.

Our Constitution states that "No one has the right to deprive or restrict the rights of citizens enshrined in our Constitution without a court decision [3]." The strict norm established by the investigation, preliminary investigation and courts prior to the investigation, which is considered a participant in the criminal proceedings, must always be followed without deviation.

\section{MATERIALS AND METHODS}

Preventing any deviation from this norm, taking strict action against the officials who committed this incident, and preventing such incidents are important in ensuring that the rights and freedoms of citizens are not violated.

The rights of citizens enshrined in our constitution may be restricted until the court's decision, that is, during the pre-trial investigation and preliminary investigation. 
If persons involved in criminal proceedings do not voluntarily exercise their rights and obligations, they may be subject to coercive procedural measures. Because coercive measures are an important procedural action, they are reflected in the restriction or temporary deprivation of personal, property and other subjective rights of citizens.

According to Article 236 of the Code of Criminal Procedure of the Republic of Uzbekistan, the precautionary measure is to prevent the accused, the defendant from evading the inquiry, preliminary investigation and court; prevention of his further criminal activity; to prevent his attempts to obstruct the truth of the case; used to ensure the execution of the sentence.

The reasonable assumption that the accused may be absconding from the inquiry, preliminary investigation and trial due to the danger of the crime provided for in the fourth and fifth paragraphs of Article 15 of the Criminal Code may also be grounds for choosing a measure of restraint in the form of detention.

Precautions should be taken against persons awaiting placement in a medical institution for examination, as well as those who have been declared mentally ill or have become mentally ill after the crime, in order to prevent their concealment and other socially dangerous acts, as well as to enforce court rulings on medical coercion. can be applied.

As a coercive procedural measure, a precautionary measure shall be applied to an accused or defendant who is a participant in criminal proceedings in accordance with Article 236 of the Code of Criminal Procedure for the following purposes:
- In order to prevent the defendant and the defendant from evading the preliminary investigation and the court;

- In order to prevent further criminal activity of the accused and defendant;

- In order to prevent attempts by the accused and the defendant to establish the truth of the case;

- In order to ensure the execution of the sentence [4].

In some cases, the measure of restraint may be applied to the suspect conditionally, ie in accordance with Article 226 (3) of the Criminal Procedure Code of the Republic of Uzbekistan. In this case, the accused must be charged within ten days from the date of his arrest. Otherwise, the precautionary measure is revoked and the person is released from custody or house arrest, and the bail is returned to the mortgagor. After the initiation of a criminal case and during the entire period of detention, the inquiry officer and investigator to whom the case relates may conduct investigative actions within their competence to determine the circumstances of the crime, to verify the validity of the detention [4].

That is, if one of the precautionary measures in the form of arrest or bail is applied to the suspect, the suspect, investigator or prosecutor conducting the preliminary investigation against the suspect must be charged within 10 days from the date of application of the measure of restraint. If the guilt is not announced, the pre-trial detention or bail will be revoked and the bail will be returned to the mortgagor.

The first part of Article 236 of the Code of Criminal Procedure sets out the grounds for the application of a precautionary measure. In 
practice, it is very common to cite these grounds for the application of precautionary measures in the form of detention.

According to the second part of Article 236 of the Code of Criminal Procedure of the Republic of Uzbekistan, a reasonable presumption that the accused may hide from the inquiry, preliminary investigation and court due to the danger of the crime provided for in the fourth and fifth parts of Article 15 of the Criminal Code. may be the basis for selection.

\section{RESULTS AND DISCUSSION}

According to Article 15 of the Criminal Code of the Republic of Uzbekistan, crimes are characterized by: their nature and level of social danger: social risk is not high; not too heavy; heavy; divided into very serious crimes.

Minor socially dangerous crimes include intentional crimes punishable by imprisonment for a term not exceeding three years, as well as crimes committed by negligence and punishable by imprisonment for a term not exceeding five years.

Minor offenses include intentional offenses punishable by imprisonment for a term exceeding three years but not exceeding five years, as well as offenses committed by negligence and punishable by imprisonment for a term exceeding five years.

Serious crimes include crimes committed intentionally and punishable by imprisonment for a term not exceeding five years, but not more than ten years, as a severe punishment under the law.

Serious crimes include those committed intentionally and are punishable by imprisonment for a term of more than ten years or life imprisonment.

Pursuant to Part 2 of Article 236 of the Code of Criminal Procedure, the accused or defendant falls into the category of serious or very serious crimes according to the nature of the crime or one of the crimes and the degree of social danger, and the accused if there is a reasonable presumption that he may be absconding from inquiry, preliminary investigation and trial, he may be remanded in custody.

Article 236 (3) of the Code of Criminal Procedure provides that "precautionary measures shall be taken against persons awaiting hospitalization for examination, as well as those who have been declared mentally ill or have become mentally ill after the crime, to prevent their hiding and other socially dangerous acts. may be applied in order to ensure the execution of a court ruling on the application of a coercive measure in the form of

In this norm, the following three categories are expected to be placed in the medical institution for examination (1); 7 precautionary measures provided for in Article 237 of the Code of Criminal Procedure for persons who have been declared mentally retarded (2) and who have become mentally ill after the commission of a crime - a receipt of appropriate conduct (1); personal guarantee, public association or community guarantee (2); bail (3); house arrest (4); arrest (5); submission of juveniles for supervision (6); one of the precautionary measures, such as command surveillance (7), may be applied to the conduct of a serviceman.

In addition, Article 236 of the Code of Criminal Procedure stipulates that a measure of 
restraint in the form of detention may be applied to a person convicted of a felony or aggravated felony and having a reasonable presumption that he may be absconding from the preliminary investigation and court. Arrest as a precautionary measure under Article 1 of the Criminal Code for intentional crimes punishable by imprisonment for more than three years and for crimes committed as a result of negligence, punishable by imprisonment for more than five years under the Criminal Code. applied on[4].

Part 2 of Article 15 of the Criminal Code of the Republic of Uzbekistan provides for imprisonment for a term of more than three years, but not more than five years, as well as negligence for a term of more than five years. the offenses committed are defined as less serious offenses.

That is, while Article 236 of the Code of Criminal Procedure applies to persons accused of committing a serious or very serious crime and there is a reasonable presumption that they may be absconding from the preliminary investigation and trial, Article 242 of the Code of Criminal Procedure commits a less serious crime. Article 2 of the Code of Criminal Procedure sets out two different norms.

The definition of these 2 different norms in the Code of Criminal Procedure causes a lot of problems in practice today, and even remains a factor that leads to corruption.

In addition, Part 2 of Article 242 of the Code of Criminal Procedure sets a stricter norm than the first part, according to which in exceptional cases the measure of restraint in the form of imprisonment for a term not exceeding three years is punishable by imprisonment for intentional crimes, as well as negligence. in the case of a crime punishable by imprisonment for a term not exceeding five years:

- When the accused or defendant is absconding from the investigation and court;

- The identity of the detained suspect has not been established;

- In case of violation of the previously applied precautionary measure by the accused, defendant;

- The detained suspect or accused, the defendant does not have a permanent residence in the Republic of Uzbekistan;

- When the crime was committed during the period of serving a sentence of imprisonment.

That is, when the accused or defendant is absconding from the preliminary investigation and court, when the identity of the detained suspect is not established, when the conditions of other measures of restraint other than previous detention are violated, when the detained suspect or accused does not have a permanent residence in the Republic of Uzbekistan. it is also prescribed to apply a measure of restraint in the form of arrest to a person who has committed a crime of low social risk when committed during the transition period.

The current legal system of the Republic of Uzbekistan belongs to the Romano-Germanic family of law, the structure of criminal and criminal procedural law and their application are very similar to the norms of criminal and criminal procedural law of the Russian Federation.

Article 242 of the Criminal Procedure Code of the Republic of Uzbekistan stipulates that pretrial detention is defined in Article 103 of the 
Criminal Procedure Code of the Russian Federation. when it is not possible to apply another type of lighter precaution against persons suspected or accused of committing the crime" called [5].

\section{CONCLUSION}

Another important condition for the application of pre-trial detention, which is provided for in this article of the Criminal Procedure Code of the Russian Federation and is not specified in the Criminal Procedure Code of the Republic of Uzbekistan, is the protection of human rights and interests. can be assessed as the appearance of doing.

I believe that the Code of Criminal Procedure of the Republic of Uzbekistan should harmonize the rules of detention and apply the measure of restraint as a last resort when it is not possible to apply other types of mitigation to suspects and accused in criminal proceedings.

This amendment prevents, firstly, the violation of the rights and freedoms of individuals in criminal proceedings, and secondly, the unjustified and unlawful detention of suspects or accused persons in the future if their guilt is not proven in court, the violation of their constitutional rights and freedoms. inconsistencies in the law are eliminated and corruption is prevented.

Therefore, the second part of Article 236 of the Criminal Procedure Code of the Republic of Uzbekistan is amended to read as follows: "A defendant who has committed a socially dangerous act punishable by imprisonment under Article Special Part of the Criminal Code and may be hidden from inquiry, preliminary investigation and court, the defendant may be remanded in custody ";

The first part of Article 242 of the Criminal Procedure Code reads as follows: "Detention as a precautionary measure is punishable by imprisonment for a term of more than three years under the Criminal Code, which is punishable by imprisonment for more than five years. shall be applied when it is not possible to apply other types of lenient measures of restraint in respect of persons suspected or accused in cases of crimes punishable by deprivation of liberty".

\section{REFERENCES}

1. Text of the President Shavkat Mirziyoyev "Speech at the solemn ceremony dedicated to the 27th anniversary of the adoption of the Constitution of the Republic of Uzbekistan", December 9, 2019

2. Constitution of the Republic of Uzbekistan Newspaper "People's Word", December 15, 1992, No. 243 (494).

3. The Constitution of the Republic of Uzbekistan the word 'national' newspaper, December 15, 1992, 243 (494), II.

4. The Criminal Procedure Code of the Republic of Uzbekistan, the Supreme Council of the Republic of Uzbekistan, 1995, No. 2.

5. "The Criminal Procedure Code of the Russian Federation" dated 18.12.2001 N 174

http://www.consultant.ru/document/c ons_doc_LAW_34481/c8855fc8d4dbb 537b17025ef67ebb5d8b1a32847 